\title{
Evaluasi Proses dan Pemecahan Masalah Desain pada Interior Hotel Holiday Inn Sunter Kemayoran - Jakarta
}

\author{
Adi Ismanto \\ Universitas Tarumanagara \\ adii@fsrd.untar.ac.id
}

\begin{abstract}
Proses desain dan pemecahan masalah desain interior pada fasilitas publik seperti hotel sangat menarik untuk dijadikan sebagai acuan dari proses belajar-mengajar desain interior di Perguruan Tinggi. Hotel merupakan fasilitas publik yang sangat kompleks mencakup berbagai macam aktivitas manusia pada semua fasilitas perancangan interior. Banyak proyek desain modern yang terlalu rumit untuk diselesaikan secara memuaskan oleh proses konvensional tua. Banyak kesalahan yang dibuat dengan proses desain, dan menjadi tidak berguna ketika desainer atau tim kerja melaksanakan proyek. Penelitian ini mencoba untuk menunjukkan fakta proses desain yang digunakan oleh desainer interior, berbagai jenis masalah dan pemecahan permasalahan desain pada hotel berbintang 4 yaitu: Holiday Inn Sunter, Kemayoran Jakarta, yang merupakan hotel Holiday Inn pertama di Jakarta yang diresmikan tahun 2014. Hotel ini juga memiliki konsep tema desain yang unik sehingga dijadikan acuan oleh pihak pengelola InterContinental Hotel Group (IHG) untuk membuat hotel Holiday Inn lainnya, terutama untuk tipe hotel Holiday Inn Express. Teknik pengumpulan data pada penelitian ini dilakukan dengan cara mewawancara desainer yang masih aktif bekerja di konsultan desain Hadiprana selaku perancang hotel ini dan mengikuti proses desain dengan beberapa pertanyaan yang ditampilkan dalam bentuk narasi, skema, dan tabel. Melalui hasil wawancara dengan desainer hotel Holiday Inn Kemayoran Jakarta dapat disimpulkan bahwa proses desain hotel Holiday Inn Kemayoran merupakan karya yang berhasil dengan gaya desain yang masih bertahan hingga saat ini. Hasil desain adalah cerminan dari Tim desain yang solid dan mampu memecahkan masalah desain dengan kreatif dan inovatif sehingga mudah dipahami dan diterima oleh klien, operator dan pengguna hotel
\end{abstract}

Kata kunci: desain interior, evaluasi, hotel, implementasi, proses desain.

\section{PENDAhuluan}

InterContinental Hotels Group (IHG) secara resmi membuka hotel Holiday Inn pertama di Sunter, Kemayoran Jakarta. Hotel Holiday Inn Kemayoran merupakan hotel bintang 4 yang didesain oleh Hadiprana sebagai salah satu konsultan desain interior dan arsitektur terbesar di Indonesia. Hasil perancangan Hotel Holiday Inn ini sangat diapresiasi oleh pemilik dan operator IHG, seperti yang dikatakan oleh Clarence Tan, Kepala Operasional IHG Se-Asia Tenggara saat peresmian hotel pada awal tahun 2014. Clarence Tan mengatakan bahwa IHG merasa senang menyambut Hotel Holiday Inn yang pertama di salah satu kota yang berkembang paling cepat di Asia.

Holiday Inn Jakarta Kemayoran berada di lokasi yang strategis, dekat dengan pusat kota Jakarta dan beberapa kawasan bisnis dan objek wisata. Desain interior Holiday Inn Sunter memiliki sub tema yang unik dengan garis tema umum yang menyatukan keseluruhan ruang yang ada, seperti restoran 
Botany/All Day Dining (Gambar. 1) dalam hotel untuk menikmati sebuah perpaduan rasa antara lokal dan internasional atau Habitat Bar Lounge (Gambar. 2) untuk bersantai dengan secangkir kopi atau memesan koktail saat pertama kali memasuki hotel atau kamar hotel yang menyajikan grafis siluet pohon yang membuat ruangan menjadi lebih tenang dan nyaman dengan pemilihan material serta warna yang sesuai.

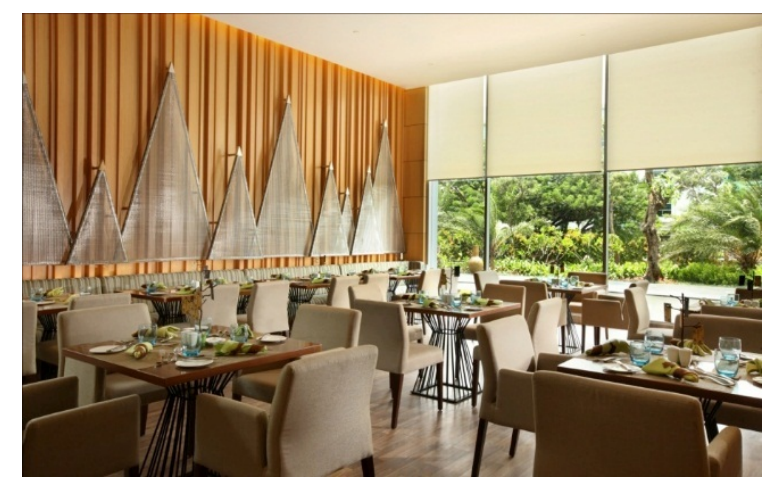

Gambar 1. Botany All Day Dining

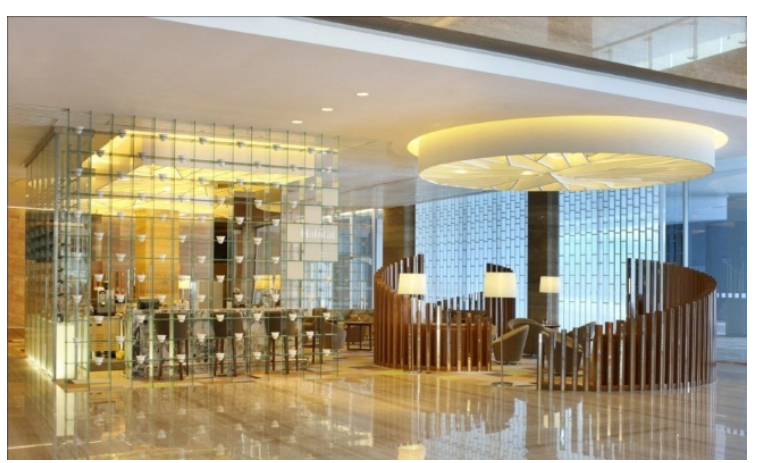

Gambar 2. Lobby Lounge Holiday Inn Sunter

Pemilihan nama dan pengolahan elemen ruang ini menjadi unik dan sangat menarik untuk diteliti bagaimana proses desain interior itu berawal. Selain itu penelitian yang menjelaskan proses desain interior secara menyeluruh, dari awal mulai perancangan, pemecahan masalah hingga post-occupancy evaluation (POE) pada fasilitas publik seperti hotel belum banyak dilakukan.

\section{METODE}

Desain penelitian ini adalah deskriptif kualitatif. Subyek penelitian yang bertindak sebagai partisipan dipilih dengan metode purposive sampling yang dipilih berdasarkan kriteria tertentu, yaitu desainer interior, akademisi, mahasiswa dan kalangan umum. Penelitian ini dilakukan di Jakarta. Instrumen penelitian yang digunakan adalah: alat perekam gambar dan suara, peralatan tulis, dan keperluan pelengkapnya. Analisis data dilakukan berdasarkan verbatim transkripsi hasil kuesioner dan wawancara pengguna jalan (in depth interview) dan observasi selama kegiatan penelitian berlangsung.

\section{HASIL DAN PEMBAHASAN}

Observasi dan wawancara dilakukan untuk mendapatkan data akurat bagaimana proses desain hingga implementasi berjalan dalam proyek ini. Narasumber adalah salah satu desainer yang masih berkerja sebagai desainer senior di konsultan desain Hadiprana yang pernah tergabung dalam tim 
desain untuk proyek Holiday Inn Kemayoran.

Kesimpulan Proses desain, pemecahan masalah dan durasi waktu yang terjadi pada proyek Holiday Inn dapat dilihat pada Tabel. 1

Tabel 1. Proses desain dan pemecahan masalah proyek Holiday Inn Kemayoran.

\begin{tabular}{|c|c|c|}
\hline $\begin{array}{l}\text { Poses } \\
\text { Desain }\end{array}$ & $\begin{array}{c}\text { Permasalahan } \\
\text { Desain }\end{array}$ & Pemecahan Masalah \\
\hline $\begin{array}{l}\text { Design } \\
\text { Brief } \\
\text { Maret } \\
2009\end{array}$ & $\begin{array}{l}\text { - Standar Operator } \\
\text { (IHG) dan Klien } \\
\text { menginginkan } \\
\text { sebuah hotel } \\
\text { bintang } 4 \text { dengan } \\
\text { konsep 'modern- } \\
\text { unique-elegant' } \\
\text { design with 'north- } \\
\text { market' oriented. }\end{array}$ & $\begin{array}{l}\text { - Lokasi yang dekat } \\
\text { pantai dan kurang } \\
\text { pohon peneduh } \\
\text { menjadi inpirasi untuk } \\
\text { menjadikan fasilitas } \\
\text { hotel sebuah tempat } \\
\text { berlindung yang sejuk } \\
\text { dengan konsep } \\
\text { “Oasis” di tengah area } \\
\text { yang panas dan } \\
\text { kering. Yang berarti } \\
\text { sebuah area terisolasi } \\
\text { dengan vegetasi di } \\
\text { area yang kering. }\end{array}$ \\
\hline $\begin{array}{l}\text { Prelimin } \\
\text { ary } \\
\text { Design } \\
\text { April } \\
2009\end{array}$ & $\begin{array}{l}\text { - Penjelasan Konsep } \\
\text { desain. } \\
\text { desain awal sebagai } \\
\text { sebuah acuan } \\
\text { referensi klien } \\
\text { untuk mendapatkan } \\
\text { gambaran desain } \\
\text { secara keseluruhan. } \\
\text { - menentukan } \\
\text { konsep desain yang } \\
\text { memiliki kesatuan } \\
\text { yang utuh sebagai } \\
\text { landasan desain. }\end{array}$ & $\begin{array}{l}\text { - Menyusun konsep } \\
\text { desain dengan tema } \\
\text { "a reflection of tree, } \\
\text { vegetations and } \\
\text { greenery". } \\
\text { - Area Lobby dibuat } \\
\text { sebagai bagian bawah } \\
\text { pohon dengan konsep } \\
\text { "The Geomatric Patern } \\
\text { of Tree Trunk" } \\
\text { - Bar Lounge di desain } \\
\text { dengan konsep } \\
\text { Vegetasi } \\
\text { - All Day Dining di } \\
\text { desain dengan konsep } \\
\text { vegatasi hutan pinus, } \\
\text { menciptakan "a dense } \\
\text { pine forest in the } \\
\text { modern graphic style". } \\
\text { - Guest Room } \\
\text { menggunakan } \\
\text { vegetasi dari bagian } \\
\text { atas pohon, dengan } \\
\text { desain yang lebih } \\
\text { "light and bright" }\end{array}$ \\
\hline
\end{tabular}

\begin{tabular}{|c|c|c|}
\hline $\begin{array}{l}\text { Design } \\
\text { Develop } \\
\text { ment } \\
\text { (Juni } \\
2009 \text { - } \\
\text { Juli } \\
2011 \text { ) }\end{array}$ & $\begin{array}{l}\text { - Pengembang } \\
\text { desain awal, } \\
\text { dengan detail pada } \\
\text { ruangan lainnya. } \\
\text { - Proses approved } \\
\text { design_untuk } \\
\text { dilanjutkan ke } \\
\text { tahap Gambar } \\
\text { Konstruksi sebagai } \\
\text { acuan pelaksanaan } \\
\text { konstruksi. }\end{array}$ & $\begin{array}{l}\text { - Mengembangkan } \\
\text { Lobby Lounge dengan } \\
\text { konsep yang lebih } \\
\text { kuat sebagai bagian } \\
\text { dari penarik perhatian } \\
\text { ruang dengan konsep } \\
\text { "Big Tree Root" } \\
\text { sebagai lounge chair } \\
\text { yang juga menjadi } \\
\text { artwork yang eye } \\
\text { catching. } \\
\text { - Pengembangan } \\
\text { Desain Executive } \\
\text { Lounge, Meeting } \\
\text { Room dan Ball Room } \\
\text { dengan konsep } \\
\text { Vegetasi dan patern } \\
\text { sarang lebah. } \\
\text { - Pengembangan } \\
\text { deain ruangan lainnya, } \\
\text { seperti: All Day Dining, } \\
\text { Health Club dan Guest } \\
\text { Room. }\end{array}$ \\
\hline $\begin{array}{l}\text { Constru } \\
\text { ction } \\
\text { Docume } \\
\text { nt } \\
\text { (Juni } \\
2009 \text { - } \\
\text { Juli } \\
2011 \text { ) }\end{array}$ & $\begin{array}{l}\text { - Proses Gambar } \\
\text { kerja dari image } \\
\text { visual desain. } \\
\text { - Penjelesan } \\
\text { Gambar Teknis dan } \\
\text { Detail. }\end{array}$ & $\begin{array}{l}\text {-Merekomendasikan } \\
\text { Manajemen } \\
\text { Konstruksi (MK) yang } \\
\text { kompeten. } \\
\text { - Komunikasi dengan } \\
\text { klien dan operator } \\
\text { untuk persetujuan } \\
\text { desain. } \\
\text { - Komunikasi dalam } \\
\text { tim desain dengan tim } \\
\text { produksi gambar } \\
\text { kerja. }\end{array}$ \\
\hline $\begin{array}{l}\text { Constru } \\
\text { ction } \\
\text { Phase \& } \\
\text { Supervi } \\
\text { sion } \\
\text { (Juni } \\
2009 \text { - } \\
\text { April } \\
2012 \text { ) }\end{array}$ & $\begin{array}{l}\text { - Proses } \\
\text { pelaksanaan } \\
\text { konstruksi sebagai } \\
\text { realisasi desain. } \\
\text { - Down spec dari } \\
\text { desain yang } \\
\text { disetujui. } \\
\text { - ketidaksesuaian } \\
\text { pelaksanaan } \\
\text { dengan desain. }\end{array}$ & $\begin{array}{l}\text {-Merekomendasikan } \\
\text { Konstraktor yang } \\
\text { kompeten. } \\
\text { - Memastikan ke klien } \\
\text { dan operator bahwa } \\
\text { desain harus sesuai } \\
\text { dilaksanakan dengan } \\
\text { arahan tim desain } \\
\text { (penyesuaian budget) } \\
\text { agar mendapatkan } \\
\text { hasil yang masksimal. } \\
\text { - Melakukan supervisi } \\
\text { berkala dan meeting } \\
\text { koordinasi dengan } \\
\text { MK. }\end{array}$ \\
\hline
\end{tabular}


Proses desain Holiday Inn sunter Komunikasi menjadi bagian utama memakan waktu kurang lebih 3 tahun hingga selesai tahapan konstruksi. Dalam prosesnya banyak permasalahan yang muncul terkait desain dan teknis pelakasanaan. Yang menjadi catatan penting dan waktu kritis dalam proses desain ini adalah bagaimana tim desain menangkap esensi dari kebutuhan dan keinginan klien terhadap produk desain yang akan dihasilkan, kemudian membuat konsep (dasar pemikiran) yang mampu menjadi acuan desain dan diterima oleh klien. Hasil kuesioner yang diberikan kepada pengguna dan operator memperlihatkan hasil yang sesuai antara permasalahan desain, pemecahan masalah dengan konsep desain dan hasil akhir yang mudah dipahami oleh pengguna dan operator, artinya desain hotel Holiday Inn Kemayoran dapat dianggap berhasil.

\section{KESIMPULAN}

terpenting untuk keberhasilan proyek ini.

Proses desain dari sebuah proyek yang sangat kompleks seperti hotel memerlukan tim yang cukup solid. Pengalaman dalam melaksanakan tipe proyek yang sama akan lebih memudahkan proses desain dalam memecahkan permalasahan yang ada, dalam hal ini konsultan sebesar hadiprana memiliki struktur organisasi yang memungkinkan untuk menghasilkan karya desain yang baik.

Permasalahan desain yang terjadi selama proses desain dan pelaksanaan proyek hotel Holiday Inn Kemayoran dapat diminimalisir semenjak awal proyek. kondisi awal persiapan klien dengan kemampuan dana yang cukup, tim manajemen konstruksi dan kontraktor yang kompeten, banyak membantu proses desain dan pelaksanaan dengan komunikasi yang tetap terjaga baik untuk hasil yang sesuai dengan arahan dan harapan klien.

Proses desain sebuah hotel adalah rangkaian proses yang sangat panjang, tetapi masa kritis berada pada proses awal dari design brief klien dan operator. Menjadi sangat penting untuk tim desain memahami kebutuhan dan keinginan klien dengan menghasilkan konsep desain yang sesuai.

\section{DAFTAR PUSTAKA}

Oscar Barros, (Mei 2007) Business Process and Architecture Design, Departemen Teknik Industri, Universitas Chili, United State of America.

Brown, T. (2009). Change by Design. New York: Harper Collins. 
Browne, M. N., Keeley, S. M. (2011) Asking

the Right Questions: A Guide to Critical

Thinking. New York: Longman.

Design Thinking. (2012). Harvard Business

Review, 86. 